\title{
The Survival of Handloom Weaving in Rural Canada Circa 1870
}

\author{
Kris Inwood AND PhYllis WAgG
}

Handloom weaving with a mixture of wool and cotton yarn was common in late nineteenth-century Canada. The hand technology survived using industrial inputs and part-time female labor whose opportunity cost was relatively low in rural areas. The demand for homespun was income-sensitive and reinforced by the cold Canadian climate. The patterns of weaving by men and women differed, but both produced for the market in addition to home consumption. Cloth constituted a significant share of farm production, especially in low-income areas.

$\mathbf{M}$ echanization and the decline of handicraft production characterized the early industrialization of North America. In the cotton industry, for example, handweaving declined during the $1820 \mathrm{~s} .{ }^{1}$ Handweaving with wool is known to have survived somewhat later, although the only close examination is Philip Scranton's study of the Philadelphia textile trades. ${ }^{2}$ William Thomson, a Scottish textile worker who toured eastern North America during the early 1840 s, found extensive handweaving in rural areas. ${ }^{3}$ Manuscript census data, personal diaries, and merchant ledgers indicate that in Canada many of the handweavers were women who used a mixture of wool and cotton yarn. Per capita Canadian production of handwoven cloth peaked around 1870 . More cloth was woven by hand in that year than on power looms. ${ }^{4}$

Thomson explained the persistence of hand technology on the grounds that North American wages were high enough to allow handweavers to support themselves with their craft. There is no doubt that

The Journal of Economic History, Vol. 53, No. 2 (June 1993). (9) The Economic History Association. All rights reserved. ISSN 0022-0507.

Kris E. Inwood is an Associate Professor of Economics, University of Guelph, Guelph, Canada N1G 2W1. Phyllis Wagg is a doctoral candidate in History, Dalhousie University, Halifax, Canada B3H 3J5.

We thank the Social Sciences and Humanities Research Council of Canada for financial support of this research. We have received useful comments from T. W. Acheson, Morris Altman, Rusty Bittermann, Elizabeth Ewan, Henry Gemery, Gay Gullickson, C. Knick Harley, Adrienne Hood, John Lyons, Doug McCalla, Marvin McInnis, Dianne Newell, participants at the 1992 Conference on Quantitative Methods in Canadian Economic History, and the editor and staff of this Journal.

'Dublin, "Women and Outwork"; Mohanty, "Putting Up"; Hood, "Organization and Extent," chap. 4; Jeremy, Transatlantic Industrial; Prude, Coming; and Ware, Early New England.

${ }^{2}$ Anonymous, Homespun, pp. 82, 102; Bidwell and Falconer, History; Blewett, Men, Women, p. 21; Cole, American Wool, vol. 1, pp. 125ff., 175ff.; Dublin, Women, p. 5; Jensen, Loosening, pp. 37-38, 50, 87-89, 134; Jeremy, Transatlantic Industrial, pp. 163ff.; Scranton, Proprietary Capitalism, pp. 220ff., 360ff.; Tryon, Household Manufactures, chap. 8; and Wright, Wool-Growing, p. 113.

${ }^{3}$ Thomson, Tradesman's Travels, pp. 129ff.

${ }^{4}$ Canada, Census, 1870-71, vol. 3, p. x; and Grant and Inwood, "Gender." 
many European handweavers emigrated in search of higher wages. ${ }^{5}$ Weavers, however, were unlikely to continue their craft in North America if other pursuits promised a higher standard of living. The available evidence suggests that immigrants with weaving skills made a relatively fast transition into farming. ${ }^{6}$ Another explanation that has been offered is that physical characteristics of the wool fiber slowed the pace of mechanization. ${ }^{7}$ Certainly, the application of power to wool and cotton differed in important respects, but North American mills as early as 1820 began to manufacture a wool-cotton blend known as satinette. ${ }^{8}$ The widespread production of satinette by both mills and handweavers effectively undermines a simple technical explanation for craft persistence. Arthur Cole and others report evidence that homespun survived latest in remote areas because of transportation cost influences. ${ }^{9}$ The example of Philadelphia, however, indicates that transportation was not the only influence. Indeed, Marvin McInnis points out that farms in older settled townships produced greater yardage than those situated farther from major market centers in Canada in $1860 .^{10}$

Transportation undoubtedly influenced the pattern of handweaving, but other factors also contributed to its persistence. The cold Canadian climate created a demand for rough wool-blend clothing, especially in areas characterized by considerable outdoor labor and low farm incomes. The gender division of labor within farm households and limited market demand for female labor in rural areas made home manufacturing one of the few ways that farm women with family responsibilities could reduce the need for factory purchases or generate cash income. Rural handweavers also benefited from their ability to purchase factoryspun cotton yarn from merchants and carding/fulling services from local mills. Evidence supporting these conclusions is drawn from a number of sources of which the most important is a collection of census manuscript data describing the activity of Canadian industrial establishments from April 1, 1870, to March 31, 1871.11

Enumerators for the 1871 Canadian census recorded cloth production

${ }^{5}$ Campbell and Dow, Source Book, p. 4; Reid, Upper Ottawa, p. 27; and Murray, Scottish Hand, chaps. $4,5$.

${ }^{6}$ The 1838 Nova Scotia census for Pictou County, an area of recent immigration, lists 19 individuals who describe themselves as weavers; those identifiable in the 1851 census describe themselves as farmers. The occupational evolution from weaver to farmer is discussed by Hood, "Organization and Extent."

${ }^{7}$ Bythell, Handloom Weavers, pp. 49ff.; Cole, American Wool, vol. 2, p. 92; and Heaton, Yorkshire Woolen, pp. 283ff., 357.

${ }^{8}$ Cole, American Wool, vol. 1, pp. 179, 199-201; and Jeremy, Transatlantic Industrial, pp. 136, 227.

${ }^{9}$ Cole, American Wool, vol. 1, pp. 279ff.; and Wright, Wool-Growing, p. 59.

${ }^{10}$ Marvin McInnis, personal communication, June 19 1987; and Lintner, "Household Behaviour."

"The data have been made machine-readable in the $1870-71$ Canadian Industrial Database; see Borsa and Inwood, Codebook. 
in two places, schedule 5 (agricultural) and schedule 6 (industrial). The need to distinguish between the two schedules arose because enumerators were instructed that homemade fabrics were to be kept distinct from those made in linen and cloth factories. In practice enumerators found it difficult to apply that distinction because the industrial establishment was defined rather broadly as

a place where one or several persons are employed in manufacturing, altering, making up or changing from one shape into another, materials for sale, use or consumption, quite irrespectively of the amount of capital employed or the products turned out.... It matters not whether the raw material is in the ownership of the manufacturer or not, whether it is transformed on account of one or another person.... The number of people employed may be made up exclusively with members of the family of the proprietor. ${ }^{12}$

By this definition every farm household processing its own wool for its own use was a factory. Systematic reliance on this definition would have left no production to be recorded on the agricultural schedule. This did not happen. Instead, enumerators distinguished between weaving for the family's own use and weaving as a business by using two criteria, the scale of production and the proportion of cloth intended for own use. ${ }^{13}$ Farm families producing cloth for their own use reported the output on schedule 5 , whereas custom weaving appeared on schedule 6 . The next census explicitly adopted this interpretation. ${ }^{14}$

Enumeration throughout most of Ontario followed a similar pattern, but the distinction between own use and custom weaving was not observed consistently in the other provinces, where enumerators made much less use of schedule $6 .{ }^{15}$ This evidence should not be viewed as an

12 Canada, Instructions, pp. 138-39.

13 The census commissioner for Middlesex North apparently asked his enumerators to indicate how they divided cloth between the two schedules. The following are representative responses. "A great many women have a loom in their house to weave their own cloth and flannel but do not follow it as a business. Those who make even a little custom work are recorded in schedule 6" (sch. 5, subdistrict E-1). "Little common handlooms in farmers houses to weave their own made yarn into cloths once a year are not returned here for not being supposed lawful establishments" (sch. 6, C-1). "The handlooms in several farmers houses doing their own weaving was considered too trifling to be returned here but the cloths and flannels produced by them in schedule no 5" (sch. 6, D-2). "Some handlooms in farmers houses who merely weave a web or two once a year for the use of the family were not lawful establishments; they did not carry on any business but their own and are returned in schedule 5" (sch. 6, D-3).

14 The 1881 compilations report upon "all establishments of importance where raw material is converted into a manufactured product for sale. They do not include such product as are made at home for family use"; see Canada, Census, 1880-81, vol. 3, p. viii. The 1871 manuscript data are especially valuable because information collected about commercial handweaving in that year does not appear to have been published in any of the census volumes. Commercial handweaving in 1881 was compiled and reported jointly with woolen mills in a category of "wool cloth making." The 1891 industrial census volume reported commercial weaving and woolen mills as distinct industrial categories. Weaving for home use was reported in the agricultural tables in all three years.

${ }^{15}$ Enumerators from across the country recorded comments such as "wove for country customers," "working by the yard for farms," "weaves for customers who furnish materials," "sold on the market," and "custom work." Other enumerators reported on schedule 6 the piece 
indication that custom or market weaving was uncommon in Quebec and the Maritimes. In Nova Scotia, for example, almost no handweaving appears on schedule 6 , even though contemporary account books confirm that numerous women wove for sale or on piece rate for merchants. ${ }^{16}$ Public postings of market prices in Nova Scotian newspapers frequently included homespun. ${ }^{17}$ Further evidence is provided by the 1850 and 1860 provincial censuses, which recorded the presence of looms. In one district 62 percent of the households reporting cloth in 1850 and 54 percent in 1860 did not have a loom. ${ }^{18}$ The most likely explanation is that farm families reported cloth made from their own wool and woven on their behalf by someone else. This implies that custom weavers were active even though schedule 6 was not used in that area. ${ }^{19}$

The data for 1870 are summarized in Table 1 . Overall production averaged 26 yards of wool and wool-blend cloth for each Canadian family. ${ }^{20}$ This figure represents somewhat less than half of all consumption, if fabric requirements were comparable to or greater than those of Pennsylvania 100 years earlier. ${ }^{21}$ Mechanization was more advanced in Ontario than in the other three provinces, but even in Ontario hand and power looms were of roughly equal importance.

Nearly a quarter of Ontario's handweaving was reported on schedule 6. We accept this figure as a lower bound for the prevalence of market weaving in all parts of the country, because of the enumeration biases noted earlier. Our picture of widespread market weaving in 1870 contrasts sharply with the American image presented by Cole, that

rate paid to weavers. In roughly one-quarter of all districts schedule 6 contains no reference to handweaving, either because there was no market weaving, or because all handwoven cloth was reported on schedule 5 .

${ }^{16}$ James Dickie Day Books (buying homespun); James Barry Account book, Nov. 1861, p. 23 (accepting cloth as payment) and July 1862 (piece rate on weaving); Hopewell Woolen Factory Cashbook, Dec. 1871 (piece rates); Peter Smyth Ledger (purchases). For New Brunswick see the Doak Mill Records (selling homespun and piece rates for spinning and weaving).

${ }^{17}$ See the Acadian Recorder during the 1850s and 1860s and Journal of Agriculture for Nova Scotia, Jan. 1866, "Parrsboro Agricultural Society Report, Nov. 7, 1865." We are indebted to R. Bittermann for these references.

18 This area comprises polling districts 16 and 17 in Pictou County.

19 We confirm our interpretation by comparing the published totals of wool and yards of farm cloth. The ratio of wool to cloth ought to be similar in different provinces. The Ontario ratio was 3.6 pounds per yard (ppy) in contrast to $0.8 \mathrm{ppy}$ in the other provinces. We attribute this sizable difference to the disappearance of Ontario wool into exports and mill consumption and to inconsistent enumeration. An adjustment for net wool exports and wool used in woolen mills brings the Ontario figure to $1.8 \mathrm{ppy}$. A further adjustment for wool used by schedule 6 handweavers brings the figure under 1 ppy and close to the adjusted figure for other provinces. These calculations assume that wool at $\mathbf{4 0}$ cents per pound accounted for two-thirds of raw material costs in woolen mills and that wool imports/exports remained in the province in which they were landed/cleared, except that 25 percent of the Quebec trade was destined for Ontario.

${ }^{20}$ Quebec and New Brunswick show lower levels of production in part because linen does not figure in this estimate.

${ }^{21}$ Hood, "Textile Consumption." 
TABLE 1

WOOL CLOTH PRODUCTION BY PROVINCE, 1870

\begin{tabular}{lcccc}
\hline & \multirow{2}{*}{$\begin{array}{c}\text { Wool Cloth } \\
\text { per Family } \\
\text { (Yards/Family) }\end{array}$} & $\begin{array}{c}\text { Schedule 5/ } \\
\text { Hand Power }\end{array}$ & $\begin{array}{c}\text { Schedule 6/ } \\
\text { Hand Power }\end{array}$ & $\begin{array}{c}\text { Schedule 6/ } \\
\text { Mechanical }\end{array}$ \\
\cline { 3 - 5 } & 25.60 & 49 & 10 & 41 \\
Canada & 27.95 & 87 & 1 & 12 \\
Nova Scotia & 20.98 & 78 & 13 & 10 \\
New Brunswick & 22.12 & 57 & 6 & 37 \\
Quebec & 25.62 & 41 & 12 & 47 \\
Ontario & & & 47 &
\end{tabular}

Sources: Canada, Census, 1870, vol. 3, table 24 (schedule 5); and 1870-71 Canadian Industrial Database. The latter is a machine-readable version of the manuscript record of industrial establishments (schedule 6 only) enumerated in the April 1871 Canadian census; see Borsa and Inwood, Codebook.

"commercial transactions in such goods was the exception, and household production for household use was the rule." 22 In Canada as well, rural weaving has been portrayed as an activity somewhat apart from the exchange economy. ${ }^{23}$ Although much of the Canadian weaving undoubtedly was for home use, the census manuscript evidence suggests that another portion was distributed to neighbors and merchants such as the Dundas County farmer who "has his own wool made into cloth for his own wear." 24 There is even some evidence of a longdistance trade in homespun, typically to provision seamen, fishermen, or forest workers, although most of the exchange relationships involving handwoven cloth appear to have existed within local communities. ${ }^{25}$

A market condition favoring the survival of handweaving was the mechanization of allied tasks such as fulling, carding, and sometimes the spinning of wool at a local mill. ${ }^{26}$ Six hundred and fifty carding and fulling mills are known to have been active in Canada in 1870. Farmers sheared their sheep at the end of the winter and brought the wool to a local mill for carding in the spring freshet. Someone in the farm family, typically the farmer's wife or daughter, spun the carded wool rolls and wove cloth that was brought back to the mill for fulling and dyeing. These mills lightened the burden of rural cloth manufacture, because

22 Cole, American Wool, vol. 1, p. 194; and Jeremy, Transatlantic Industrial, p. 219.

${ }^{23}$ Cohen, Markets.

${ }^{24}$ Canada West, Transactions, 1860-3, pp. 21-22.

${ }^{25}$ Reid, Upper Ottawa, pp. 174-78; Nancy Ann Harris Account Book; Gesner, Industrial Resources, p. 211; Ruddel, "Consumer Trends," fn. 40; and New Brunswick Courier, Oct. 1835, shipping news column. (We are grateful to Alan McNeil for this reference.) Douglas McCalla argues for the importance of local exchange even in a region better known for its production of exportables. McCalla, "The Internal Economy."

${ }^{26}$ William Thomson indicates that many carding mills also spun yarn, although the 1870 industrial manuscripts indicate that spinning was more commonly combined with weaving than carding alone. Thomson, Tradesman's Travels, p. 29. A few independent wool spinning mills also functioned in 1870 . 
TABLE 2

COST STRUCTURE OF HANDWOVEN FULLED CLOTH CIRCA 1870

\begin{tabular}{lcc}
\hline \hline \multicolumn{1}{c}{ Activity } & $\begin{array}{c}\text { Value Added } \\
\text { (Cents per Yard) }\end{array}$ & $\begin{array}{c}\text { Apparent Share of } \\
\text { Final Value (\%) }\end{array}$ \\
\hline Raw wool & 17 & 25 \\
Carding and oiling & 5 & 7 \\
Spinning wool & 6 & 9 \\
Cotton yarn & 14 & 20 \\
Weaving & 10 & 14 \\
Fulling and dyeing & 17 & 25 \\
\hline
\end{tabular}

Notes: The calculations assume 0.6 pounds of wool and 0.3 pounds of cotton per yard. The price per pound of raw wool is 29 cents; carding and oiling, 9 cents; spinning, 10 cents; and cotton yarn, 48 cents.

Sources: Values are retrieved from commodity detail in the 1870-71 Canadian Industrial Database (see Borsa and Inwood, Codebook) with the exception of fulling and dyeing, which is from Grant Mill advertisements, Eastern Chronicle, June 16 and 23, 1870. Money values here and elsewhere are reported in Canadian dollars and cents. See also the Doak Mill Records, the Hopewell Woolen Mill Cashbook, and the James Dickie Daybooks.

hand carding and fulling were particularly arduous tasks. ${ }^{27}$ The relative importance of the various stages of production is documented in Table 2 , which shows that the activities occurring most typically on farms (raw wool, spinning, and weaving) contributed about one-half of final value.

The survival of handweaving was also facilitated by the provision of cotton yarn, brought from New England mills to the rural weaver by rail and steamship. ${ }^{28}$ The use of cotton by rural weavers is confirmed in two ways. An authoritative survey of nineteenth-century fabrics contains photographic plates and descriptions of 415 individual pieces of handwoven cloth that have survived in modern collections. ${ }^{29}$ Three-quarters of the pieces have cotton as a warp, a weft, or both. Cotton also appears with some frequency in the schedule 6 industrial returns. Not all records provide input detail, and in many cases the information may be incomplete. Records that include some information about inputs are described in Table 3. Almost all mention or imply the use of wool. Seventy-seven percent of the returns mention cotton whereas only 9 percent refer to linen. These are lower-bound estimates because some records are incomplete. ${ }^{30}$

The extensive use of cotton attracts attention because it was not a

${ }^{27}$ A description of hand-fulling may be found in MacKenzie, Highland Community, pp. 41-42. Gay Gullickson and Katrina Honeyman and Jordan Goodman provide other examples of hand technology surviving in part because allied tasks were mechanized. Gullickson, Spinners and Weavers; and Honeyman and Goodman, "Women's Work," p. 618.

${ }^{28}$ By 1874 at least one New Brunswick mill manufactured cotton warps; see Dominion Board of Trade, Report, 1874, p. 97. There was no handspinning of cotton; see Burnham and Burnham, "Keep Me Warm," p. 17.

${ }^{29}$ Burnham and Burnham, "Keep Me Warm."

${ }^{30}$ Many firms reported an output of "flannel and other cloth" with an input of "yarn." The output indicates' wool, because flannel was either a wool-cotton blend or all wool, but we cannot be sure about the use of cotton. 
TABLE 3

CHARACTERISTICS OF WOOL HANDWEAVING BY TYPE OF FIBER, 1870

\begin{tabular}{lcccc}
\hline \multicolumn{1}{c}{ Fiber } & $\begin{array}{c}\text { Share of All } \\
\text { Records (\%) }\end{array}$ & $\begin{array}{c}\text { Average } \\
\text { Product } \\
\text { (Yards) }\end{array}$ & $\begin{array}{c}\text { Share of } \\
\text { Firms with } \\
\text { One Worker (\%) }\end{array}$ & $\begin{array}{c}\text { Female Share of } \\
\text { Workers (\%) }\end{array}$ \\
\hline Wool only & 20 & 493 & 86 & 76 \\
Wool and cotton & 71 & 580 & 80 & 73 \\
Wool and linen & 3 & 511 & 84 & 80 \\
Wool, cotton, and linen & 6 & 439 & 83 & 77 \\
\hline
\end{tabular}

Note: The tabulation includes records with at least some input detail. This understates the use of cotton, as explained in the text.

Source: 1870-7I Canadian Industrial Database; see Borsa and Inwood, Codebook.

native material. The first cloth woven in many North American communities used wool and linen, which could be produced within the rural community. ${ }^{31}$ By the 1820 s most weavers had begun to substitute factory-spun cotton for handspun linen, and the change inevitably brought weavers into exchange relationships with merchants or with people who dealt with merchants. By itself, this information says little about "mentalité," but the widespread purchase of industrial inputs removes any possibility that rural weavers functioned in self-sufficient isolation from the larger commercial world of exchange relationships. ${ }^{32}$ Quite the opposite-weavers were able to continue their craft because they actively participated in a variety of markets.

The weaver faced market pressures of a different sort with the widespread availability of factory textiles. Estate inventories confirm that many households purchased both local handwoven and imported factory cloth. ${ }^{33}$ Even weaving families purchased factory cloth. ${ }^{34}$ Homespun occupied a particular niche in the consumption of rural households. Most handwoven cloth appears to have been used to fashion shirts, trousers, and other clothing. Blankets, coverlets, counterpanes, rugs, sheets, and related fabric appear in less than 10 percent of the schedule 6 records; the most commonly mentioned products are satinette and flannel used in the manufacture of clothing. ${ }^{35}$

It is easy to understand the demand for wool and wool-blend clothing. Daytime temperatures below five degrees centigrade are common

\footnotetext{
${ }^{31}$ Burnham and Burnham, “Keep Me Warm,” p. 26; Coons, Linen-Making, p. 27; and Rivard, Home Manufacture.

32 For a sample of the "mentalite" debate, see Rothenberg, "The Market"; and Vickers, "Competency."

${ }^{33}$ Field, "Lunenburg"; Ruddel, "Textile Production"; and Ruddel, "Consumer Trends."

${ }^{34}$ Women in at least one family washed, picked, carded, spun, and wove their own wool, in addition to putting out wool to a custom weaver and purchasing store cloth for other purposes; see Campbell, "Susan Dunlap."

${ }^{35}$ Costume accounts for only 20 percent of the cloth pieces surveyed because blankets, carpets, and especially coverlets survived more easily than the everyday costume of work and play. See Burnham and Burnham, "Keep Me Warm," p. 79. British weavers had begun to make a worsted weft on a cotton warp as opposed to the wool weft common in North America. See Bythell, Handloom Weavers, pp. 261ff.; and Lyons, "Family Response," p. 73.
} 
everywhere in Canada for half of the year. In 1870 the economy was still structured around outdoor activities for which workers needed protection from the cold. The primitive nature of interior heating apparatuses and the effort needed to acquire wood fuel created a demand for warm indoor clothing as well. In these conditions there was no substitute for wool and wool-blend cloth in the manufacture of shirts, trousers, and undergarments.

A family's decision to produce some of its own clothing rather than purchase factory-made apparel was in part a reflection of income. Dorothy and Harold Burnham suggest that handweaving was relatively more important in parts of Canada characterized by low farm incomes. ${ }^{36}$ A recent estimate of relative regional incomes confirms this hypothesis. ${ }^{37}$ Further evidence comes from estate inventories. Terry Ruddel finds that groups with higher socioeconomic status held larger shares of wealth in clothing, but that a lower proportion of the clothing was homespun. ${ }^{38}$ Contemporary remarks also suggest that the substitution of factory cloth for homespun was part of a transformation of consumption patterns influenced by rising incomes.

At the beginning of this period milled cloth was but little used, and while the better class of farmers had at least a Sunday dress of English cloth, the large majority were clad in homespun, undressed and dyed at home. ${ }^{39}$

I could wear home-spun in those days. Clothing didn't cost me anything then, but after my time if a teacher appeared in home-spun in the school-house the children would have driven him out. ... The sturdy home-spun was no longer the respected symbol of virtuous woman's industry; now it was the scorned by the rising generation as the symbol of outmoded poverty. ${ }^{40}$

The old-fashioned home-made cloth has given way to the fine broadcloth coat: the linsey-woolsey dresses of females have disappeared, and English and French silks [been] substituted; the nice clean-scoured floors of the farmers' houses have been covered by Brussels carpets; the spinning wheel and loom have been superseded by the piano; and, in short, a complete revolution in all our domestic habits has taken place. ${ }^{41}$

Even year-to-year fluctuations influenced the choice between factory and handwoven cloth. Ontario's carding and fulling mills were busy in 1860 because farm income was low.

The hard times which have existed throughout the country for the past year or two have rather increased their business, for farmers have doffed the broad cloth and taken to the homespun. ${ }^{42}$

${ }^{36}$ Burnham and Burnham, "Keep Me Warm," pp. 8-10.

${ }^{37}$ Inwood and Irwin, "Canadian Regional."

${ }^{38}$ Ruddel, "Consumer Trends."

${ }^{39}$ Patterson, History. The use of homespun for weekday or working purposes in emphasized as well by Eaton, History, pp. 215-17.

${ }^{40}$ Dunn, Highland Settler, p. 120. Peter Cumming reports that "children tried to tear their homemade clothing so they could get 'store bought." Cumming, Story, p. 50.

${ }^{41}$ Jones, History, p. 21.

42 Journal of the Board of Arts and Manufactures of Canada West, p. 114. 
Although handweaving was integrated into local and larger markets, it was a solitary enterprise in the sense that most weaving shops involved only one person working in a shed or backroom of a rural home. The data in Table 3 confirm that most weavers worked alone. Historians agree that weaving for household use tended to be women's work, but there has been a debate about the gender of professional weavers during the nineteenth century. ${ }^{43}$ The evidence reported in Table 3 is that women were responsible for about three-quarters of the commercial weaving establishments recorded on schedule 6 .

Few, if any of the schedule 6 weavers were professional in the sense of earning a living solely from their craft. The levels of individual output and income imply that handweaving survived as a part-time activity complementing the other activities of rural families. ${ }^{44}$ Average yardage was about 500 yards per year, for which a typical Ontario piece rate was 10 cents per yard (Table 2). With the addition of wool production and home spinning, the total value generated by the typical schedule 6 weaver amounted to approximately one-quarter of average income per family in Canada in $1870 .{ }^{45}$ This estimate describes commercial or custom weaving only. Yardages were significantly smaller in households consuming all of their own cloth. The only way to examine the overall importance of weaving to the rural economy is to calculate the share of farm income derived from hand-woven cloth of all types. Estimates of this type suggest that cloth contributed as much as one-tenth of farm income in eastern Canada from 1850 to $1870 .^{46}$

We derive further insight into the nature of rural society by examining differences between male and female custom weavers. Each schedule 6 record lists a proprietor, who in most cases was the only worker. ${ }^{47}$ The average male-headed firm produced about three times the yardage of female weavers (Table 4). Male-headed firms worked a greater number of months during the year and were more likely to have a second worker. In most cases this worker was a female, probably the weaver's wife. Male proprietors had 50 percent greater capital per worker and

${ }^{43}$ Burnham, The Comfortable Arts; Burnham and Burnham, "Keep Me Warm," p. 6; Grant and Inwood, "Gender"; Grant and Inwood, "Labouring"; and Ruddel, "Textile Production."

44 Weaving may have been closer to a full-time activity for the rural craftsmen described by Thomson 30 years earlier since they apparently earned a reasonable income at a similar piece rate. Thomson notes that "the condition of the custom weavers all over the States and Canada is equal, if not superior to that of the country weavers in Scotland some forty years ago." Thomson, $A$ Tradesman's Travels, p. 129.

${ }^{45}$ Income per family in 1870 is gross domestic product divided by the number of families. See Urquhart, "New Estimates."

${ }_{46}$ Acheson, "The Condition"; and Inwood and Wagg, "Wealth and Prosperity."

${ }^{47}$ The Canadian 1870 census counted the proprietor as a worker if she or he worked in the establishment. In some cases the proprietor did not work. This situation occurred most commonly with a male proprietor and one or more female workers. Almost certainly these were family businesses in which the male head of family did not work but claimed proprietorship because he was interviewed by the enumerator. Several hundred establishments were enumerated in this way. 
TABLE 4

CHARACTERISTICS OF WOOL HANDWEAVING BY SEX OF PROPRIETOR

\begin{tabular}{lrrr}
\hline & Female & Male & All \\
\hline Number of records & 1,923 & 798 & 2,830 \\
Average product (yards) & 388 & 1,008 & 563 \\
Average capital (\$) & 36 & 64 & 47 \\
Average month's activity & 4.2 & 6.7 & 4.9 \\
Percentage of firms with one worker & 89 & 68 & 79 \\
Female/all workers & .97 & .25 & .73 \\
Percentage of firms with workers of the opposite sex & 3 & 27 & 10 \\
Average population density of the local environment & 77 & 189 & 127 \\
$\quad$ (people/square mile) & & & \\
\hline
\end{tabular}

Notes: The male- and female-headed firms do not sum to the total because the gender of some names could not be determined. Population density is calculated for the census subdistrict (CSD) in which each establishment was located. About 370 families lived in the average CSD.

Source: 1870-71 Canadian Industrial Database; see Borsa and Inwood, Codebook.

produced 50 percent greater yardage for every month of activity. Perhaps the most intriguing difference is that the environment of women weavers was, on average, substantially more rural than that of male weavers. Almost all weavers of both sexes lived and worked in relatively rural areas, but the typical female weaver lived and worked in a township that was less densely populated than her male counterpart.

Although male weavers worked more months per year and more hours per month, the majority of cloth recorded in schedule 6 was made by women. Most of them lived in farm households where they assumed primary responsibility for the manufacture and washing of clothing; the care of children and boarders, the gathering of water, the care of small animals and cows, vegetable and fruit production, food processing of butter and cheese, and maintenance of the farm, whereas men worked elsewhere, seasonally or otherwise. In many families women helped with the harvest, and young women worked away from home as servants almost as often as their brothers worked as laborers. ${ }^{48}$ In these circumstances it is not surprising to find that women wove on a part-time basis.

The gender division of labor among rural families reflected social and cultural influences as well as the physical conditions of agriculture. Whatever the precise balance of causes, the outcome in a market sense was a lower opportunity cost of a woman's time for nonagricultural activities such as weaving. Every available source confirms that wage rates for women in rural Canada during the nineteenth century were at most half that of men. ${ }^{49}$ Claudia Goldin and Ken Sokoloff argue the

\footnotetext{
${ }^{48}$ Prentice, Canadian Women; and Crowley, "Unequal Inheritance."

49 Crowley, "Unequal Inheritance." The opportunity cost of time may have been even lower than the market wage inasmuch as weaving was only one of a matrix of farm household activities best analyzed in a joint production framework. We are grateful to Frank Lewis for this point.
} 
significance of this point for northern industrialization. ${ }^{50}$ McInnis explores its implications for the fertility transition in Canada. ${ }^{51}$ Another consequence was the late persistence of preindustrial craft technologies such as weaving in the hands of rural women.

The significance of late nineteenth-century handweaving was not as a protoindustrial harbinger of subsequent factory production. Indeed, the parts of Canada where handweaving persisted longest were not the areas that industrialized most rapidly. Rather, the importance of homespun lay in its contribution to the local economy and to the daily work routines of rural women. A recognition of handicraft survival also cautions us to be skeptical about any model of industrialization that specifies or implies a gradual and continuous transfer of manufacturing from the home to the factory, or from female to male labor. The single most influential theme in the literature about North American manufacturing is the effect of land abundance in raising real wages and encouraging capital-intensive, large-scale forms of industrial technology. ${ }^{52}$ This powerful insight should not blind us to the fact that some handicrafts survived quite late within households organized around the family farm, which, as a basis for organizing agricultural production and as a social institution, owed its existence to the abundance of land.

so Goldin and Sokoloff, "Women, Children."

sI McInnis, "Women."

52 Habakkuk, American and British Technology.

\section{REFERENCES}

Acadian Recorder (various years).

Acheson, T. W., "The Condition of New Brunswick Agriculture on the Eve of Confederation," in Kris Inwood, ed., Farm, Factory and Fortune: New Essays in the Economic History of the Maritimes (Fredericton, 1993), pp. 37-61.

Anonymous, Homespun to Factory Made (North Andover, 1977).

Barry, James, Account Book, Public Archives of Nova Scotia, MG 1, vol. 1222.

Bidwell, Percy, and John Falconer, History of Agriculture in the Northern United States, 1620-1860 (New York, 1941).

Blewett, Mary, Men, Women and Work: Class, Gender and Protest in the New England Shoe industry, 1780-1910 (Chicago, 1988).

Borsa, Joan, and Kris Inwood, Codebook and Interpretation Manual for the 1870-71 Canadian Industrial Database (Guelph, 1993).

Burnham, Dorothy, The Comfortable Arts (Ottawa, 1981).

Burnham, Dorothy, and Harold Burnham, "Keep Me Warm One Night," Early Handweaving in Eastern Canada (Toronto, 1972).

Bythell, Duncan, The Handloom Weavers (Cambridge, 1969).

Campbell, G. G., "Susan Dunlap: Her Diary," Dalhousie Review (1966), pp. 215-22.

Campbell, R. H., and J. B. A. Dow, Source Book of Scottish and Economic History (Oxford, 1968). 
Canada, Census (various years and volumes).

Canada, Department of Agriculture, Instructions to Enumerators, Sessional Paper No. 64 (Ottawa, 1871).

Canada West, Transactions of the Board of Agriculture of Canada West, 1860-63.

Cohen, Marjorie, Markets and Economic Development in Nineteenth-Century Ontario (Toronto, 1988).

Cole, Arthur Harris, The American Wool Manufacture, 2 vols. (Cambridge, 1926).

Coons, Martha, Linen-Making in New England, 1640-1860 (North Andover, 1980).

Crowley, Terry, "Unequal Inheritance: Rural Labour in Nineteenth-Century Ontario," in Paul Craven, ed., Labouring Lives (Toronto, forthcoming).

Cumming, Peter, The Story of Framboise (Framboise, Nova Scotia, 1984).

Dickie, James, Daybooks, Dalhousie University Archives, MS 4-63.

Doak Mill Records, Public Archives of New Brunswick, MS1 K1 and MS8 F1.

Dominion Board of Trade, Report, 1874.

Dublin, Thomas, Women at Work (New York, 1979).

Dublin, Thomas, "Women and Outwork in a Nineteenth-Century New England Town," in Steve Hahn and Jonathon Prude, eds., The Countryside in the Age of Capitalist Transformation (Chapel Hill, NC, 1985), pp. 51-69.

Dunn, Charles, Highland Settler: A Portrait of the Scottish Gael in Cape Breton and Eastern Nova Scotia (Toronto, 1953).

Eastern Chronicle, June 1870.

Eaton, Arthur, The History of King's County, Nova Scotia (Salem, 1910).

Field, Richard, "Lunenburg German Household Textiles," Material History Bulletin, 24 (Fall 1986), pp. 16-23.

Gesner, Abraham, The Industrial Resources of Nova Scotia (Halifax, 1848).

Goldin, Claudia, and Ken Sokoloff, "Women, Children and Industrialization in the Early Republic," this Journal, 42 (Dec. 1982), pp. 741-74.

Grant, Janine, and Kris Inwood, "Gender and Organization in the Canadian Cloth Industry," Canadian Papers in Business History, 1 (1989), pp. 17-32.

Grant, Janine, and Kris Inwood, "Labouring at the Loom: A Case Study of Rural Manufacturing," Canadian Papers in Rural History, 7 (1990), pp. 215-36.

Gullickson, Gay L., Spinners and Weavers of Auffay (Cambridge, 1986).

Habakkuk, H. J., American and British Technology in the Nineteenth Century: The Search for Labour-Saving Inventions (New York, 1962).

Harris, Nancy Ann, Account Book, Public Archives of New Brunswick, MC 456, MS 1, 1858-1869.

Heaton, Herbert, The Yorkshire Woolen and Worsted Industries (Oxford, 1965).

Honeyman, Katrina, and Jordan Goodman, "Women's Work, Gender Conflict and Labour Markets in Europe, 1500-1900," Economic History Review, 44 (Nov. 1991), pp. 608-28.

Hood, Adriensne, "Organization and Extent of Textile Manufacture in Eighteenth Century Rural Pennsylvania"' (Ph.D. diss., University of California at San Diego, 1988).

Hood, Adrienne, "Textile Consumption in Eighteenth-century Rural Pennsylvania: Domestic Production versus Imported Fabrics" (Unpublished paper, Toronto, 1990).

Hopewell Woolen Mill, Cashbook, Public Archives of Nova Scotia, Manuscript Group 3, vol. 232.

Inwood, Kris, and Jim Irwin, "Canadian Regional Commodity Income Differences at Confederation," in Kris Inwood, ed., New Essays in the Economic History of the Maritimes (Fredericton, 1993), pp. 149-70.

Inwood, Kris, and Phyllis Wagg, "Wealth and Prosperity in Nova Scotia Agriculture, 
1850-1870" (Paper presented to the Canadian Historical Association, Charlottetown, Prince Edward Island, 1992).

Jensen, Joan, Loosening the Bonds (New Haven, 1988).

Jeremy, David J., Transatlantic Industrial Revolution: The Diffusion of Textile Technologies Between Britain and America, 1790-1830s (Cambridge, 1981).

Jones, Robert L., History of Agriculture in Ontario (Toronto, 1946).

Journal of Agriculture for Nova Scotia, Jan. 1866.

Journal of the Board of Arts and Manufacturers of Canada West, Jan. 14, 1861.

Lintner, Anastasia, "Household Behaviour and the Allocation of Time: The Case of Cloth Production on Ontario Farms in 1860" (M.A. thesis, University of Guelph, 1990).

Lyons, John, "Family Response to Economic Decline: Handloom Weavers in Early Nineteenth-Century Lancashire," Research in Economic History, 12 (1989), pp. 45-92.

McCalla, Doug, “The Internal Economy of Upper Canada," Agricultural History, 59 (July 1985), pp. 397-416.

McInnis, Marvin, "Women, Work and Childbearing," Social History/Histoire sociale, 24 (Nov. 1991), pp. 237-62.

MacKenzie, P. J., Highland Community on the Bras d'Or (Halifax, 1978).

Mohanty, Gayle Fowler, "Putting Up with Putting-Out," Journal of the Early Republic, 9 (Summer 1989), pp. 191-216.

Murray, Norman, The Scottish Hand Loom Weavers, 1790-1850 (Edinburgh, 1978).

New Brunswick Courier, Oct. 1835.

Nova Scotia, Census of Pictou County (Halifax, 1838).

Patterson, George, A History of the County of Pictou (Montreal, 1877).

Prentice, Alison, et al., Canadian Women: A History (Toronto, 1988).

Prude, Jonathon, The Coming of Industrial Order: Town and Factory Life in Rural Massachusetts, 1810-1860 (Cambridge, MA, 1983).

Reid, Richard, ed., The Upper Ottawa Valley to 1885 (Toronto, 1990).

Rivard, Paul, The Home Manufacture of Cloth (Pawtucket, RI, 1974).

Rothenberg, Winifred, "The Market and Massachusetts Farmers, 1750-1855," this JoURnal, 41 (June 1981), pp. 283-314.

Ruddel, D. Terry, "Textile Production in Colonial Quebec, 1609-1840," Material History Bulletin, 31 (Spring 1990), pp. 39-50.

Ruddel, D. Terry, "Consumer Trends, Clothing, Textiles and Equipment in the Montreal Area," Material History Bulletin, 32 (Fall 1990), pp. 45-64.

Scranton, Phillip, Proprietary Capitalism (Cambridge, 1983).

Smyth, Peter, Ledger, Public Archives of Nova Scotia, Manuscript Group 3, vol. 285. Thomson, William, A Tradesman's Travels (Edinburgh, 1842).

Tryon, Rolla, Household Manufactures in the United States (Chicago, 1917).

Urquhart, M. C., "New Estimates of Gross National Product, Canada, 1870-1926," in Stanley Engerman and Robert Gallman, eds., Long-Term Factors in American Economic Growth (Chicago, 1986), pp. 9-94.

Vickers, Daniel, "Competency and Competition: Economic Culture in Early America," William and Mary Quarterly, 47 (1990), pp. 1-28.

Ware, Carolyn, The Early New England Cotton Manufacture (Boston, 1931).

Wright, Chester, Wool-Growing and the Tariff (Cambridge, 1910). 